\title{
PERFECTION OF PRE-SCHOOL CHILD'S SPEECH OF DIALOGUE AND VOCABULARY DURING THE PROCESS OF GETTING ACQUAINTED WITH BOOK ILLUSTRATION
}

\author{
Agrita Taurina \\ Riga Teacher Training and Educational Management Academy, Latvia \\ Dagnija Vigule \\ Riga Teacher Training and Educational Management Academy, Latvia
}

\begin{abstract}
Very topical issue in many situations nowadays is caused by parent busyness, aloofness among family members, and alienation in mutual relationships; therefore, in families too little attention is devoted to many-sided development of child's abilities, too little time is spent on direct, emotional contact in conversation. During the survey on the preschool education and development of vocabulary carried out by 54 educators, the more and less well known topics were found out. Children are open to and interested in communication to find out how things work, developing their own vocabulary with the guidance of skilled teachers and parents. Book illustration analysis as well as the forms of conversation realization used in the research is in line with those carried out in the Project No NFI/R/2014/053 "Latvian in Monolingual and Bilingual Acquisition: tools, theories and applications".
\end{abstract}

Keywords: education, pre-schooler, speech of dialogue, vocabulary.

\section{Introduction}

The dynamic processes and diverse environment of our everyday life determines the necessity of appropriate communication ability for everyone. The wholesome and necessary part of a developed person is the ability to take part in the dialogue, to argument his or her opinion, to defend it and to understand the partner's speech appropriately. Thus, the main conditions of one's successful social experience we can indicate are the following:

- dialogues have to ensure different communication functions (informative, regulatory, emotionally critical, expressive, socially cultural etc);

- the sequence from simple to more difficult, from reproductive to productive has to be observed;

- the use of gestures, intonations, motions as well as the learning and observing the speech etiquette has to be included in dialogue speech learning process; 
- to understand the theme, to realize the addressee and to plan the appropriate content, to choose the language means has to be taught;

- to control ones' speech, to appraise it, as well as to evaluate others' speech from the content from the cultural point of view need to be taught (Anspoka, 2008).

The basic linguistic terminology dictionary gives the explanation of the dialogue as two or more person's speech - the language form, where every expression of the speaker is directly addressed to the partner (The basic linguistic terminology dictionary, 2007). In order to speak at least two active speech partners are needed. Besides, everybody is a speaker and a listener at the same time (Apsalons, 2013). So it means that speaking itself is as important as listening and questioning. L. Dubkevičs also points that all these actions are happening simultaneously. In order to learn the communication skills, one has to learn the appropriate way of speaking, listening and questioning (Dubkēvičs, 2006). The rich, correct, developed language and skilled speech allows to define one's thoughts quickly and accurately, as well as to perceive other partners' thoughts appropriately. Thus it is very important condition for the individual to self-realize in the society.

The ideal aim of the dialogue or the communication is the process of understanding: to understand what other say, the interaction of understanding, the ability to understand also the nonverbal language (Šuvajevs, 2007). The information obtained during dialogue process has been processed: perceived, recognized and interpreted. Simultaneously, during the information obtaining process speaker learns to hear the partner and to treat him tolerantly, to understand himself and others. Scientist N. Saprigina described the mechanism of understanding in dialogue and divided the acting of addressee into three stages: perception, understanding and effectiveness (Saprigina, 2003).

The dialogue allows a child to express his thoughts out loud and to negotiate them with others. It is the process where he or she learns to think, to discuss, to communicate with people, to perceive others. High level of understanding ensures wide range of possibilities to make positive relationships between people: the individual is ready for dialogue, opened to different points of view, observes the cultural standards.

Dialogue speech is built up not only on the sequence of words and sentences, but also on the sequence of thought expressed in words and correctly formed sentences and replicas. With the help of dialogue a child accomplishes several tasks - obtains information with a certain aim thus presenting its active position in the relationships with a partner (communicating, cooperating, representing respect and attention), influences the partner with his speech behaviour, modelling his own world with a certain content (Stangaine, Dzintere, 2007). 
Speech development is closely connected with the surrounding world and depends on the acquired life experience. As the acquired experience grows up, child's vocabulary develops and becomes richer, as well as the dialogue speech is completed effectively. The primary function of the speech is communicative. Speech is the important mean of social communication as well as that of understanding and expressing. L. Vigotskis points out that speech implements not only communicative but also the function of thinking (Vigotskis, 2002). Already being a baby he tries to report something to others thus proving how important for a child is to express his own thoughts, to tell something, to negotiate, to assure, to obtain the information, to share the experience (Markus, 2003). Nevertheless, although this information proves that a pre-school child is eager to have dialogue with others, his abilities are still developing (Salkind, Margolis, Ruyck, Rasmussen, 2006). Thus a pedagogue has to develop a child's ability not only to communicate between themselves, but also to support the development of dialogue speech and vocabulary expansion.

The development of a child's speech is determined by listening and adult's speech imitating. During this age, speech develops from the egocentric form to dialogue, listening and contextual speech: a child tries to follow the logical flow of other's speech and thoughts. The development derives in several stages. At first, a child concentrates his attention to the subject of the speech, is fixing the result or process of the action. Then he passes to planning, plans what and how he will act. Later the egocentric speech is substituted by the inner speech (Vigotskis, 2002). In pre-school stage it is essential to support the development of proficient communication skills.

Child's language reflects such basic concepts like qualities - heavy and light, as well as learns connection between objects and concepts. Besides a child realizes how to generalize and finally knows how to understand such expressions like hard work; brilliant head; a warm personality etc. A child acquires language through searches and findings, mistakes and experience, demonstrating his knowledge in specific words as well as general opinion usage. D. Markus points out that children like to imitate a lot. Many adults are smiling when observing child - "wise man". Many little girls are imitating their mothers, the way they are speaking on the phone with their friends, or make-up procedures in front of the mirror enriching the effect with screaming and sighs (Markus, 2003).

The ability to use speech freely in sense of self-expression and mean of dialogue speech is considered the important factor of person's socialization. In this case linguistic speech has strictly practical function. Although speech is only one of the means of communication, E. Kramiñš emphasises it as one of the most significant component explaining that a person as a social being can accomplish and meet his physiological needs, safety, love and affiliation, 
recognition, knowledge, aesthetic, self-actualisation and other needs for the most part only with the help of speech. (Kramiņš, 2005).

The aim of the study is to get theoretical and practical knowledge about perfection of vocabulary and pre-school child's speech during the process of getting acquainted with book illustration. Research is based on the analysis of theoretical literature and the empirical method - observation of 13 children of mixed ages (5-7 years) during the pedagogical process in Riga pre-school education establishment. Analysis of child's vocabulary about characterization of book illustration shows importance of child's imagination, ability to see various objects or events in indefinite forms, creates an opportunity to develop speech of dialogue. If child refuses to explain drawing, within a further communication adult has to offer his own experience characterising ideas that may be seen in unclear forms or suggest several versions of what may be seen in such pieces of art. The methods used in the research work are connected with the Project No NFI/R/2014/053 "Latvian in Monolingual and Bilingual Acquisition: tools, theories and applications" sound pronunciation and vocabulary content definition and carrying out.

\section{Results}

When speaking and learning the world a child develops his speech in its phonetical, lexical, (the knowledge of vocabulary and word meaning), syntax (making the statements, thought argumentation etc) aspects. By the communication (speech pattern studying, ability to see the new, unknown and to learn its meaning or make his own word; to form and ask the questions, listen to answers, react to them, start and end the conversation etc,), he develops his dialogue speech abilities, using verbal, visual, audio and other information, obtained through his lifetime in direct or eventual way.

The main tasks to promote the dialogue speech development and vocabulary enrichment for pre-school children are:

- To study psychological, social and linguistic aspects of children dialogue speech;

- To enlarge and analyse preschool child's dialogue speech empiric material, as well as social requirements and values of behaviour;

- To study the language of 5-7 year old monolingual (Latvian) children in natural dialogue situations (spontaneous speech);

- To analyse the means of pedagogical work, considering child's dialogue speech skills and dictionary.

As to J. Puzanova, the language professionals have started the studying process of children dictionary relatively in recent times. In comparison, the adult 
dictionary in its language usage aspect has been studied and presented for almost thousands of years, since Aristotle's stated categories, whereas children' s language has been the object of interest for language professionals for only last hundred years (Puzanova, 2010).

In the next preschool period a child wants to learn more, his interest about the world and language rises. In order to enlarge the vocabulary, it is important to enrich the vocabulary, to promote the understanding of the word meaning, word content and to activate the usage of the new vocabulary.

This work goes in hand with a child's psycho-emotional and intellectual development. T. Babajeva and L. Rimaševska (2012) points that in nowadays i.e. 21st century children are much more informed and use different technological devices with interest, communicate freely, feel themselves very confident in communication, are more open to new knowledge, whereas the ethical values and manners of politeness learns with difficulties. This tendency is so characteristic to children nowadays causes many conflicts during communication process, it corresponds to elder children inability to concentrate to tasks they are fulfilling, as well as to sedentary lifestyle.

In order to learn children dialogue speech abilities looking at the pictures, Russian scientists from Russian State Pedagogical institute T. Babajeva, A. Gogoberidze and Z. Mihailova (2010) in their book "Monitoring in kindergarten" have published dialogue speech evaluation criteria. They point that very important element is to respect children point of view of ethical values, to learn their personal experience and their ability to create the dialogue and exchange replies according to the situation. The criteria for dialogue speech and communication abilities evaluation are characterized in "Tab. 1."

Table 1 Child's dialogue speech evaluation criteria looking at the illustration's content (collected by T. Babajeva, A. Gogoberidze and Z. Mihailova)

\begin{tabular}{|l|c|c|}
\hline \multicolumn{1}{|c|}{ Children dialogue speech evaluation criteria } & $\begin{array}{c}\text { Evaluation } \\
\text { in points }\end{array}$ & $\begin{array}{c}\text { Dialogue } \\
\text { speech level }\end{array}$ \\
\hline $\begin{array}{l}\text { 1. A child is interested in communication, takes an active part in it } \\
\text { and is able to argument his point of view, is able to identify the } \\
\text { connection of the events; demonstrates confident, accurate replies, } \\
\text { expresses his thoughts sequentially; asks questions }\end{array}$ & 3 & $\begin{array}{c}\text { High dialogue } \\
\text { speech level }\end{array}$ \\
\hline $\begin{array}{l}\text { 2. A child answers the questions in simple sentences or easy } \\
\text { compound sentences; mostly takes part in the dialogue with } \\
\text { answers, not explaining causes and consequences, has difficulties } \\
\text { to explain them with language help. }\end{array}$ & 2 & $\begin{array}{c}\text { Medium } \\
\text { dialogue } \\
\text { speech level }\end{array}$ \\
\hline $\begin{array}{l}\text { 3. A child demonstrates low level of activity in communication, } \\
\text { mostly keeps silent, says only few words, mostly listens not } \\
\text { speaks }\end{array}$ & 1 & $\begin{array}{l}\text { Low dialogue } \\
\text { speech level }\end{array}$ \\
\hline $\begin{array}{l}\text { 4. A child refuses to take part in communication and to express } \\
\text { his point of view when speaking about the picture }\end{array}$ & 0 & $\begin{array}{l}\text { Refusal to take } \\
\text { part in } \\
\text { communication }\end{array}$ \\
\hline
\end{tabular}


Agrita Taurina, Dagnija Vigule. Perfection of Pre-School Child's Speech of Dialogue and Vocabulary During the Process of Getting Acquainted with Book Illustration

5-7 year old children were included in research work and they demonstrated mostly medium to high dialogue speech level. For example a girl $\mathrm{G}(5 ; 0)$ looking at the picture where a boy is yanking a cat by the tail, and the cat is scratching him, explains the situation:

G: A boy wanted to play with his cat, he yanked him by the tail and a cat scratched the boy.

G: I don't like that the boy is yanking the cat by the tail, it is bad because it hurts.

G: I don't yank my cat by the tail and he doesn't bite me.

$G$ : The boy says to the cat - sorry, sorry.

G: Don't scratch me, because it hurts, I just want to play with you.

G: It is not allowed to step on cat's tail.

G: I would stroke the cat.

Whereas a boy R. $(5 ; 7)$ takes part in the dialogues speech only with few replies, is not explaining causes and consequences, he demonstrates his attitude briefly.

$R:$ A boy pulls cat's tail.

$R$ : He pulls the cat.

$R:$ And a cat scratches.

$R$ : I would stroke the cat.

R: Wouldn't hurt him.

A girl M. $(5 ; 11)$ in the dialogue speech explains her point of view and accepts aggressive behaving. Her statements are demonstrating unwillingness to resolve the situation using the words, but to accept the physical pressure.

M: I see how a boy yanks a cat by the tail and a cat scratches with his claws a boy's cheek.

M: I like when a cat scratches a boy.

M: A cat says meow to a boy.

Although a girl D. $(5 ; 0)$ appraises a picture very intensely looking at the children - some children are playing, some are arguing and fighting, still girl's comments grammatically could be more correct and the sequence of events could be explained more.

D: They don't look friendly.

D: These are friendly. A teddy bear is thirsty.

D: Look there! A teddy bear is sad, but he's happy because he got drink!

D: A mug is on the floor!

D: Let's put it on the shelf!

D: With that who gave a drink to teddy bear.

D: A girl says: "Thank you for giving me a teddy bear."

$D$ : I won't give you that mug!

D: A teddy bear says: "Hey, girl! My head is upside down!" 
A boy D. $(6 ; 0)$ is brief, his dialogue speech is that of medium level, but at the same time, he demonstrates understanding of ethical values and polite behaviour.

D: Children are playing and fighting.

D: That's not good that they are fighting.

D: Fighting is bad.

D: Do you want tea?

D: I'd play.

A boy K. $(6 ; 0)$ explains the events depicted in the picture about children helping their grandma to tidy up the mess in the kitchen, when nobody else helps. A boy K. characterizes the positive actions, and features his choice.

$K$ : I see a boy is looking, he's peeling potatoes, the other boy is cutting something, a girl is cooking something, a granny is wondering what is on the table.

K: I like when a boy is peeling the potatoes, because he helps his parents.

$K$ : I'd do the same, I'd tidy up the table.

A boy H. $(5 ; 0)$ describes the situations with a great interest, correctly points to the unsafe actions, and explains that he wants to help. The boy operates with a wide range of words.

$H$ : Everybody's doing something.

H: Most probably they help their mum to cook.

H: A girl is cooking, I think she roasts meat.

H: A boy in red pullover is peeling potatoes and the other boy is cutting something, most probably those already peeled potatoes.

H: To my mind, a boy in red pullover is working the best.

$H$ : He's peeling potatoes and that is hard.

H: I like that he works so.

H: My mom doesn't allow to work with a knife, I'll peel the potatoes when I'll be ten.

H: Everything is upside down. What a mess!

H: A chair is upside down, potato peels are on the floor and the knife is on the floor.

H: It's not safe. Somebody can step on the knife and can hurt himself.

H: Everything has crashed, also the oven is falling down.

H: There's something burnt, it looks like potatoes and meat.

$H$ : The kitchen is untidy.

H: Granny is scared, she thinks who has done it.

$H$ : Oh, I think I know, look, there are children in the other room.

$H$ : They're watching TV, most likely a cartoon.

H: Oh, I know, they're watching a film about dragons, that one what is on TV in the mornings. 
Agrita Taurina, Dagnija Vigule. Perfection of Pre-School Child's Speech of Dialogue and Vocabulary During the Process of Getting Acquainted with Book Illustration

H: Granny calls all of them to the kitchen, but nobody hears her.

H: Most likely they're afraid that granny will scold them.

$H$ : If I could I'd help granny to tidy up.

$H$ : She's old and it's hard for her to do everything.

Table 2 Children produced speech results for book illustrations

\begin{tabular}{|c|c|c|c|c|c|c|c|c|c|c|c|c|c|}
\hline \multirow[t]{2}{*}{ No. } & \multicolumn{2}{|c|}{$\begin{array}{c}\text { Produced } \\
\text { speech } \\
\text { form }\end{array}$} & \multirow{2}{*}{ 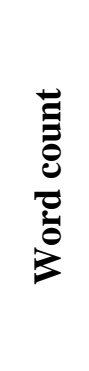 } & \multicolumn{10}{|c|}{ Word class } \\
\hline & : & 를 & & $\begin{array}{l}\Xi \\
Z \\
Z\end{array}$ & : & 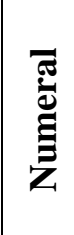 & 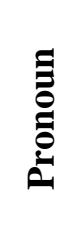 & $\stackrel{0}{\vdots}$ & 这 & 章 & نี & 包 & 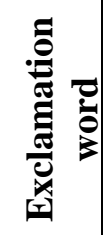 \\
\hline \multicolumn{14}{|c|}{ The firs illustration - Cat } \\
\hline R_b $(5,7)$ & 5 & & 16 & 6 & & & 2 & 5 & 2 & & 1 & & \\
\hline D_g (5) & 7 & & 60 & 12 & 1 & 2 & 10 & 16 & 9 & 1 & 3 & 3 & 1 \\
\hline M_g $(5,11)$ & 3 & & 24 & 11 & & & 2 & 6 & 1 & 2 & 1 & & 1 \\
\hline K_b (6) & 4 & & 29 & 10 & & & 3 & 8 & 1 & 2 & 3 & & 1 \\
\hline G_g (5) & 7 & & 63 & 16 & & & 12 & 19 & 4 & 6 & 5 & & \\
\hline D_b (6) & 4 & & 20 & 5 & & & 3 & 5 & 4 & 1 & 1 & & 1 \\
\hline L_b (5) & 8 & & 44 & 11 & 1 & & 7 & 13 & 4 & 1 & 7 & & \\
\hline G_b $(5,5)$ & 12 & & 65 & 16 & 3 & & 6 & 17 & 4 & 6 & 9 & 1 & 3 \\
\hline E_g (5) & 7 & & 35 & 11 & & & 5 & 9 & 4 & 2 & 4 & & \\
\hline P_g $(5,3)$ & 6 & 2 & 49 & 5 & 2 & & 14 & 10 & 4 & 1 & 9 & 3 & 1 \\
\hline H_b (5) & 13 & & 90 & 29 & & & 9 & 27 & 8 & 4 & 10 & 2 & 1 \\
\hline R_b $(6,8)$ & 13 & 2 & 113 & 20 & 3 & 1 & 20 & 30 & 20 & 4 & 12 & 3 & \\
\hline J_b (6) & 5 & & 52 & 13 & & & 5 & 15 & 6 & 9 & 4 & & \\
\hline \multicolumn{14}{|c|}{ The second illustration - The toys } \\
\hline R_b $(5,7)$ & 15 & 1 & 59 & 17 & 1 & & 4 & 22 & 6 & 1 & 7 & & \\
\hline D_g (5) & 10 & & 59 & 17 & 4 & & 13 & 17 & 2 & 2 & 3 & & 1 \\
\hline M_g $(5,11)$ & 4 & & 30 & 6 & & & 6 & 8 & 4 & 3 & 2 & 1 & \\
\hline K_b (6) & 4 & & 40 & 10 & & & 6 & 14 & 4 & 1 & 3 & & 2 \\
\hline G_g (5) & 4 & & 54 & 13 & & 1 & 12 & 14 & 2 & 1 & 7 & 1 & 2 \\
\hline D_b (6) & 4 & 1 & 16 & 2 & & & 1 & 8 & 2 & & 2 & & 1 \\
\hline L_b (5) & 7 & & 28 & 8 & & & 4 & 9 & 4 & & 3 & & \\
\hline G_b $(5,5)$ & 11 & & 56 & 10 & 1 & & 9 & 18 & 7 & 1 & 6 & & 4 \\
\hline E_g (5) & 7 & 1 & 56 & 21 & & & 8 & 15 & 2 & 2 & 6 & & \\
\hline$P \_g(5,3)$ & 3 & 1 & 19 & 3 & & & 2 & 7 & 1 & 2 & 2 & & 2 \\
\hline H_b (5) & 20 & & 121 & 31 & 4 & & 14 & 34 & 12 & 8 & 13 & 5 & 1 \\
\hline R_b $(6,8)$ & 23 & & 163 & 34 & 6 & 2 & 40 & 38 & 18 & 5 & 11 & 3 & 6 \\
\hline J_b (6) & 8 & & 76 & 20 & & 5 & 7 & 23 & 12 & 3 & 6 & & \\
\hline
\end{tabular}




\begin{tabular}{|l|l|l|l|l|l|l|l|l|l|l|l|l|l|}
\hline \multicolumn{1}{|l|}{ The third illustration - In the kitchen } \\
\hline R_b (5,7) & 12 & & 59 & 11 & 2 & & 14 & 21 & 4 & & 6 & 1 & \\
\hline D_g (5) & 10 & 1 & 49 & 21 & 1 & & 3 & 14 & 3 & 2 & 4 & 1 & \\
\hline M_g (5,11) & 4 & & 33 & 8 & & 3 & 2 & 12 & 4 & 2 & 1 & & 1 \\
\hline K_b (6) & 4 & & 40 & 10 & & 1 & 6 & 13 & 5 & 1 & 4 & & \\
\hline G_g (5) & 7 & & 64 & 14 & 3 & 1 & 10 & 23 & 8 & 1 & 4 & & \\
\hline D_b (6) & 7 & & 32 & 8 & 2 & & 1 & 14 & 2 & & 4 & & 1 \\
\hline L_b(5) & 8 & 1 & 48 & 9 & 1 & & 4 & 17 & 8 & & 7 & 1 & 1 \\
\hline G_b (5,5) & 8 & 2 & 53 & 10 & 1 & 1 & 7 & 20 & 2 & & 7 & & 5 \\
\hline E_g(5) & 7 & & 44 & 17 & & & 3 & 15 & 1 & & 6 & & \\
\hline P_g (5,3) & 10 & 1 & 45 & 9 & & & 3 & 14 & 2 & & 12 & 1 & 4 \\
\hline H_b (5) & 22 & & 179 & 36 & 8 & 3 & 34 & 49 & 12 & 8 & 20 & 7 & 2 \\
\hline R_b (6,8) & 9 & & 114 & 20 & 3 & 1 & 19 & 36 & 15 & 2 & 12 & 6 & \\
\hline J_b (6) & 13 & & 127 & 38 & 1 & 4 & 19 & 44 & 12 & 1 & 4 & 3 & 1 \\
\hline
\end{tabular}

We've found that children in dialogue about image situations use predominately verbs and nouns. The greatest of such numbers seen regard illustrations in the kitchen with verbs (33\%), nouns (23\%), compared to the other parts of speech. The least of children 1 to $3 \%$ in dialogue used numerals and adjectives, for example, the cat. The children used a one number word to describe the situation conceived. This indicates that the child has the ability in great detail to describe the situation. In order to evaluate children word range, the result charts are made as well as the results of the illustration "2.Tab."

In appointed book illustrations for the Project different successful and the problematic actions and scenes are observed. This ensures the possibility during the conversation to have child's point of view, to determine his attitude and to explain adult's personal experience. In order to encourage the child to join the conversation with interest and develop his willingness to speak, the pedagogue used the following questions:

What activities can be seen?

Which children actions do you like the most and why?

What do you think children are saying to each other?

How would you behave if you were they?

Unfortunately, the 54 teachers in the survey results indicate that they are the main problem. Our targeted implementation in advancing teacher assistant skill is lost in negotiations. It is the difficult to co-operate with teacher assistants, who do not perceive the dialogue speech development role and avoid active involvement in the educational process. It is noted that preschools lack of image recognition are in low numbers regarding posters about collecting items. It explains how teachers sometimes lacking these skills replaced speech development with table game card viewing. Useful yes but primarily suitable for individual or subgroup game situations. 
Agrita Taurina, Dagnija Vigule. Perfection of Pre-School Child's Speech of Dialogue and Vocabulary During the Process of Getting Acquainted with Book Illustration

\section{Conclusions}

The process of book illustration research and content discussion promotes the rich vocabulary. Managing and solving the problematic situation process using the productive questions and illustration analysis, is the proper key to child's socio-emotional growth and dialogue speech development. If pedagogues and parents demonstrate the ability to solve everyday situations using dialogues as communication form, children are successful in cooperation with adults and their mates. In communication with children an adult has to use nonverbal communication means like gesturing, manners, encourage him and demonstrate natural, sincere and true support. That is the main precondition to develop and maintain child's interest in vocabulary and dialogue speech expansion. The material obtained in the Project No NFI/R/2014/053 "Latvian in Monolingual and Bilingual Acquisition: tools, theories and applications" will be applied and analysed in sound pronunciation and vocabulary research process.

\section{References}

Anspoka, Z. (2008). Latviešu valodas didaktika.1. - 4.klase. Rīga: Raka.

Apsalons, E. (2011). Valodas lietojuma logika. Ievads elementārajā logikīa un zinātniskajā argumentācijā. Kultūras zinātnes filozofija. Rīga: Zvaigzne ABC.

Dubkēvičs, L. (2006). Saskarsme audzēkņiem. Rīga: Jumava.

Dzintere, D., Stangaine, I. (2007). Rotaļa - bèrna dzīvesveids. Rīga: RaKa.

Kramiņš, E. (2005). Runas prasme saziñā. Rīga: Turība.

Markus, D. (2003). Bērna valoda: no pirmā kliedziena lìdz pasakai. Rīga: Rasa.

Piažē, Ž. (2002). Bērna intelektuālā attīstība. Pētergailis.

Salkind, N.J., Margolis, L., Ruyck, K.D., Rasmussen, K. (2006). Encyclopedia of Human Development. Thousand Caks: Sage Publication.

Šuvajevs, I. (2007). Filosofija kā dzīvesmāksla. Rīga: Zvaigzne ABC.

Valodniecības pamatterminu skaidrojošā vārdnīca. (2007). Rīga: LU Latviešu valodas institūts.

Vigotskis, L.. (2002). Domāšana un runa. Rīga: Eve.

Бабаева, Т.И., Гогоберидзе, А.Г., Михайлова, З.А. (2010). Мониторинг в детском саду. СПб: Детство-пресс.

Бабаева, Т.И., Римашевская, Л.С. (2012). Как развивать взаимоотношения и сотрудничество дошкольников в детском саду. СПб: Детство-пресс.

Пузанова, Ю.С. (2010). Семантические группь параметрических прилагательных русского языка в адъективном словаре ребенка. Освоение русского языка как первого и как второго (неродного): коллективная монография/сост. Т.А. Круглякова. - СПб.: Златоуст.

Сапрыгина, Н. В. (2003). Психолингвистика диалога. Москва: ТЭс. 